\title{
PENGARUH SISTEM PENGENDALIAN INTERN PEMERINTAH TERHADAP EFEKTIVITAS PENGELOLAAN KEUANGAN PADA BADAN PENGELOLA KEUANGAN DAN ASET DAERAH KABUPATEN MUSI BANYUASIN
}

\author{
Jumania Septariani \\ STIE Rahmaniyah Sekayu \\ Email:jseptariani@gmail.com \\ Rano Asoka \\ STIE Rahmaniyah Sekayu \\ Email : ranoasoka09@gmail.com
}

\begin{abstract}
This study aims to determine the effect of the government's internal control system on the effectiveness of the regional financial management of the Musi Banyuasin Regency Government. The types and sources of data used by the author in this study are primary and secondary data. In this study, the author used quantitative analysis techniques. The results of the study stated that the government internal control system in the Government of Musi Banyuasin Regency was adequate, this was supported by research indicators namely elements of the government's internal control system consisting of the control environment, risk assessment, control activities, information and communication and monitoring. The effectiveness of regional financial management in the Musi Banyuasin District Government is very effective, this is supported by research indicators, namely the objectives of regional financial management consisting of responsibilities, being able to fulfill financial obligations, honesty, efficiency and effectiveness and effective and controlling activities. There is an influence of the government's internal control system on the effectiveness of regional financial management in the Musi Banyuasin District Government.

Keywords: Government Internal Control System, Effectiveness and Management of Regional Finances
\end{abstract}

\section{PENDAHULUAN}

Pengendalian internal dalam pemerintahan memang dirasa perlu untuk menghindari tindakan kecurangan yang mungkin ataupun telah dilakukan oleh berbagai pihak dalam instansi pemerintah. Dalam melaksanakan pengendalian internal, pemerintah mengacu pada Peraturan Pemerintah Nomor 60 Tahun 2008 tentang Sistem Pengendalian Intern Pemerintah. Namun dalam kenyataannya pengendalian ini belum maksimal diterapkan dalam aktivitas pemerintah.

Sistem pengendalian internal pemerintah belum seluruhnya diperbaiki, kerjasama antara pihak pemerintah, wakil rakyat dan lembaga masyarakat untuk memperbaiki sistem dalam pengelolaan keuangan negara. Sudah banyak ditemukan 
dalam organisasi sektor publik yang pengelolaan keuangannya dengan tidak memperkuat pengendalian internalnya dengan makin banyak terjadi penyelewengan dana anggaran demi kepentingan pribadi.

Fenomena yang menjadi dasar penelitian ini adalah adanya hasil pemeriksaan Badan Pemeriksa Keuangan (BPK) atas 542 Laporan Keuangan Pertanggungjawaban Daerah (LKPD) Tahun 2018 ditemukan 5.858 kelemahan Sistem Pengendalian Intern (SPI) yang terdiri atas 1.826 permasalahan kelemahan sistem pengendalian akuntansi dan pelaporan, 2.753 permasalahan kelemahan sistem pengendalian pelaksanaan anggaran pendapatan dan belanja, dan 1.279 permasalahan kelemahan struktur pengendalian intern. Komposisi permasalahan kelemahan SPI tersebut. Kelemahan dalam penerapan Sistem Pengendalian Intern (SPI) dapat saja mengakibatkan kerugian negara, potensi kerugian negara, kekurangan penerimaan, penyimpangan administrasi, ketidakhematan, ketidakefisienan atau ketidakefektifan.

Selain permasalahan SPI, hasil pemeriksaan BPK mengungkapkan 6.259 permasalahan ketidakpatuhan terhadap ketentuan peraturan perundang-undangan. Permasalahan tersebut meliputi permasalahan ketidakpatuhan yang dapat mengakibatkan kerugian, potensi kerugian, dan kekurangan penerimaan (berdampak finansial) sebanyak 4.001 permasalahan sebesar Rp. 2,19 triliun, serta penyimpangan administrasi (tidak berdampak finansial) sebanyak 2.258 permasalahan. Permasalahan ketidakpatuhan yang berdampak finansial meliputi permasalahan ketidakpatuhan terhadap ketentuan peraturan perundang-undangan yang dapat mengakibatkan kerugian sebanyak 2.642 permasalahan sebesar Rp. 1,30 triliun, potensi kerugian sebanyak 426 sebesar Rp. 308,85 miliar dan kekurangan penerimaan sebanyak 933 permasalahan sebesar Rp. 577,78 miliar. Atas permasalahan ketidakpatuhan tersebut, selama proses pemeriksaan entitas telah menindaklanjuti dengan melakukan penyetoran uang ke kas negara/ daerah atau penyerahan aset sebesar Rp. 434,78 miliar.

Kabupaten Musi Banyuasin adalah salah satu kabupaten di Provinsi Sumatera Selatan dengan ibukota Kota Sekayu yang memiliki luas wilayah $\pm 14.265,96 \mathrm{~km}^{2}$ yang terbentang pada lokasi $1,3^{\circ}-4^{\circ} \mathrm{LS}, 103^{\circ}-105^{\circ} \mathrm{BT}$, di 
Kabupaten Musi Banyuasin keuangan daerah dikelola oleh Badan Pengelolah Keuangan dan Aset Daerah (BPKAD).

Beberapa Tahun terakhir Kabupaten Musi Banyuasin mendapatkan opini Wajar Tanpa Pengeculaian (WTP) sebanyak 4 (empat) kali berturut-turut (Tahun 2016-2019). Namun masih banyak ditemukan penyimpangan di Kabupaten Musi Banyuasin yang mengindikasikan bahwa pada pemerintah Kabupaten Musi Banyuasin masih banyak terdapat kelemahan, baik itu kelemahan pada Sistem Pengendalian Akuntansi dan Pelaporan, kelemahan pada Sistem Pengendalian Pelaksanaan Anggaran Pendapatan dan Belanja, atau kelemahan pada Struktur Pengendalian Intern. Kelemahan tersebut dapat disebabkan oleh kurang memadainya kompetensi SDM pengelola keuangan pada pemerintah daerah ataupun penyajian laporan keuangan yang belum sesuai dengan Standar Akuntansi Pemerintahan (SAP).

Permasalahan lainnya yang berkaitan dengan SPI pada Pemerintah Kabupaten Musi Banyuasin yaiu permasalahan ketidakpatuhan terhadap ketentuan peraturan perundang-undangan yang dapat mengakibatkan kerugian dan potensi kerugian atas LKPD. Oleh karena itu, Pemerintah Kabupaten Musi Banyuasin harus menerapkan sistem pengendalian intern (SPI) dengan baik agar tidak terjadi kerugian dan potensi kerugian di kemudian hari.

\section{LANDASAN TEORI}

\section{Konsep Sistem Pengendalian Intern Pemerintah}

Peraturan Pemerintah Nomor 60 Tahun 2008 tentang Sistem Pengendalian Intern Pemerintah, Sistem Pengendalian Intern adalah proses yang integral pada tindakan dan kegiatan yang dilakukan secara terus menerus oleh pimpinan dan seluruh pegawai untuk memberikan keyakinan memadai atas tercapainya tujuan organisasi melalui kegiatan yang efektif dan efisien, keandalan pelaporan keuangan, pengamanan aset negara, dan ketaatan terhadap peraturan perundangundangan. Unsur-unsur sistem pengendalian intern pemerintah, yaitu Lingkungan pengendalian, Penilaian risiko, Kegiatan pengendalian, Informasi dan Komunikasi, Pemantauan. 


\section{Tujuan Sistem Pengendalian Intern Pemerintah}

Menurut tujuannya pengendalian intern dirancang untuk memberikan jaminan bahwa tujuan organisasi akan dapat dicapai melalui efisiensi dan efektivitas operasi, penyajian laporan keuangan yang dapat dipercaya, dan ketaatan terhadap undang-undang dan aturan yang berlaku seperti yang tertera dalam pengertian pengendalian menurut COSO Tahun 2009.

Sedangkan tujuan sistem pengendalian intern pemerintah menurut Peraturan Pemerintah Nomor 60 Tahun 2008 tentang Sistem Pengendalian Intern adalah untuk memberikan keyakinan yang memadai tentang; Tercapainya efektivitas dan efisiensi pencapaian tujuan penyelenggaraan pemerintahan negara, Keandalan pelaporan keuangan, Pengamanan aset negara, Ketaatan terhadap peraturan perundang-undangan.

\section{Unsur Sistem Pengendalian Intern Pemerintah}

Agar mencapai pengendalian intern yang memadai maka diperlukan beberapa komponen pengendalian intern seperti yang diungkapkan COSO Tahun 2009. Penelitian Committee of Sponsoring Organizations of the Treadway Commission (COSO) mengatakan bahwa pengendalian intern sebagai proses yang diimplementasikan oleh dewan komisaris, pihak manajemen, dan mereka yang ada di bawah arahan keduanya untuk memberikan jaminan yang wajar bahwa tujuan pengendalian dapat tercapai. Pengendalian intern memberikan jaminan yang wajar, bukan absolute, karena kemungkinan kesalahan manusia, kolusi, dan penolakan manajemen atas proses pengendalian membuat proses ini menjadi tidak sempurna.

\section{Efektivitas Pelaksanaan Pengelolaan Keuangan Daerah}

Pengelolaan Keuangan Daerah menurut Peraturan Pemerintah Nomor 12 Tahun 2019 tentang Pengelolaan Keuangan Daerah, keseluruhan kegiatan yang meliputi tentang proses perencanaan, pelaksanaan, penatausahaan, pelaporan, pertanggungjawaban dan pengawasan keuangan daerah. Sedangkan menurut Halim (2012:7), pengelolaan keuangan daerah merupakan pengelolaan anggaran daerah (APBD). Pengelolaan Keuangan Daerah dilaksanakan dalam suatu sistem yang terintegrasi yang diwujudkan dalam APBD yang setiap tahun ditetapkan dengan 
peraturan daerah. Pemegang kekuasaan pengelolaan keuangan daerah mempunyai kewenangan yaitu menetapkan kebijakan tentang pelaksanaan APBD, menetapkan kuasa pengguna anggaran/barang dan menetapkan pejabat yang bertugas melakukan pengelolaan utang dan piutang daerah.

\section{Pengaruh Sistem Pengendalian Intern Pemerintah Terhadap Efektivitas Pengelolaan Keuangan Daerah}

Pemberian otonomi daerah berarti pemberian kewenangan dan keluaran (direksi) kepada daerah untuk mengelola dan memanfaatkan sumber daya daerah secara optimal. Agar tidak terjadi penyimpangan dan penyelewengan pemberian wewenang dan keleluasaan harus diikuti dengan pengawasan dan pengendalian yang kuat, serta pemeriksaan yang efektif yang dilakukan pihak yang telah ditentukan melalui perundang-undangan yang berlaku yang memliki tanggungjawab kepada wakil rakyat (legislatif). Pengawasan dilakukan oleh pihak luar eksekutif (dalam hal DPR, DPRD dan masyarakat).

Pengendalian yang berupa pengendalian internal dan pengendalian manajemen berada di bawah kendali eksekutif (pemerintah pusat dan daerah) dan dilakukan untuk memastikan strategi dijalankan dengan baik sehingga tujuan dapat dicapai, sedangkan pemeriksaan (audit) dilakukan oleh badan yang memiliki kompetensi dan indepedensi untuk mengukur apakah kinerja eksekutif sudah sesuai dengan kriteria yang telah ditetapkan.

Menurut Peraturan Pemerintah Nomor 60 Tahun 2008 tentang Sistem Pengendalian Intern Pemerintah Pasal 2 menyatakan bahwa: untuk mencapai pengelolaan keuangan negara yang efektif, efisien, transparan, dan akuntabel, menteri/pimpinan lembaga, gubernur, dan bupati/walikota wajib melakukan pengendalian atas penyelenggaraan kegiatan pemerintahan. Artinya apabila sistem pengendalian intern pemerintah diselenggarakan dengan baik maka efektivitas pengelolaan keuangan daerah akan tercapai.

\section{METODOLOGI PENELITIAN}

\section{Lokasi Penelitian}

Dalam setiap penelitian yang dilakukan perlu adanya objek penelitian, begitu juga dengan penelitian ini. Objek penelitian ini adalah Badan Pengelola 
Keuangan dan Aset Daerah Kabupaten Musi Banyuasin, yang beralamatkan Jalan

Kolonel Wahid Udin Kecamatan Sekayu Kabupaten Musi Banyuasin.

\section{Populasi, Sampel dan Teknik Pengambilan Sampel}

Dalam penelitian ini yang menjadi populasi adalah Pengawai Negeri Sipil (PNS) Badan Pengelola Keuangan dan Aset Daerah Kabupaten Musi Banyuasin yaitu sebanyak 38 pegawai yang terdiri dari 13 PNS bidang akuntansi, 13 PNS bidang perbendaharaan dan 12 PNS bidang anggaran. Dalam penelitian ini tidak digunakan teknik sampling jenuh karena sampel yang diteliti adalah keseluruhan dari populasi yang ada atau disebut dengan sensus yaitu pengambilan sampel yang diambil dari seluruh jumlah populasi yaitu berjumlah 38 pegawai.

\section{Operasionalisasi Variabel}

Kriteria pengukuran terhadap masing-masing variabel penelitian sesuai indikator di atas, dapat digambarkan melalui Tabel 1 berikut:

\section{Tabel 1}

Operasionalisasi Variabel Penelitian

\begin{tabular}{|c|c|c|c|c|c|}
\hline No. & Variabel & Variabel & Sub Variabel & Item & Skala \\
\hline 1 & $\begin{array}{c}\text { Sistem } \\
\text { Pengendalian } \\
\text { Intern } \\
\text { Pemerintah } \\
\text { (X) }\end{array}$ & $\begin{array}{lr}\text { Menurut } & \text { Peraturan } \\
\text { Pemerintah Nomor } 60 \text { Tahun } \\
2008 \text { tentang } \\
\text { Pengendalian } \\
\text { Pemerintah, Intern } \\
\text { Pengendalian Intern adalah } \\
\text { proses yang integral pada } \\
\text { tindakan dan kegiatan yang } \\
\text { dilakukan secara terus } \\
\text { menerus oleh pimpinan dan } \\
\text { seluruh pegawai untuk } \\
\text { memberikan keyakinan } \\
\text { memadai atas tercapainya } \\
\text { tujuan organisasi melalui } \\
\text { kegiatan yang efektif dan } \\
\text { efisien, keandalan pelaporan } \\
\text { keuangan, pengamanan aset } \\
\text { negara, dan ketaatan terhadap } \\
\text { peraturan perundang- } \\
\text { undangan. }\end{array}$ & $\begin{array}{l}\text { 1. Lingkungan } \\
\text { Pengendalian } \\
\text { 2. Penilaian Resiko } \\
\text { 3. Kegiatan } \\
\text { Pengendalian } \\
\text { 4. Informasi \& } \\
\text { Komunikasi } \\
\text { 5. Pemantauan }\end{array}$ & $\begin{array}{l}1-2 \\
3-4 \\
5-6 \\
7-8 \\
9-10\end{array}$ & Ordinal \\
\hline 2 & $\begin{array}{l}\text { Efektivitas } \\
\text { Pengelolaan } \\
\text { Keuangan } \\
\text { Daerah } \\
\text { (Y) }\end{array}$ & $\begin{array}{l}\text { Halim (2012:74), menyatakan } \\
\text { efektivitas dalam pengelolaan } \\
\text { keuangan daerah adalah } \\
\text { penyelesaian kegiatan tepat } \\
\text { pada waktunya dan di dalam } \\
\text { batas anggaran yang tersedia, } \\
\text { dapat berarti pula pencapaian }\end{array}$ & $\begin{array}{l}\text { 1. Tanggungjawab } \\
\text { 2. Mampu } \\
\text { Memenuhi } \\
\text { Kewajiban } \\
\text { Keuangan } \\
\text { 3. Kejujuran }\end{array}$ & $\begin{array}{l}1-2 \\
3-4\end{array}$ & Ordinal \\
\hline
\end{tabular}




\begin{tabular}{|l|l|l|l|l|}
\hline & $\begin{array}{l}\text { tujuan dan sasaran yang telah } \\
\text { direncanakan. }\end{array}$ & $\begin{array}{l}\text { 4. Hasil Guna dan } \\
\text { Kegiatan Efisien } \\
\text { dan Efektif } \\
\text { 5. Pengendalian }\end{array}$ & 9-10 & \\
& & & \\
\hline
\end{tabular}

Sumber: Peraturan Pemerintah Nomor 60 Tahun 2008 dan Halim (2012:74)

\section{Teknik Pengumpulan Data}

Adapun teknik pengumpulan data yang digunakan oleh Penulis pada penelitian ini adalah sebagai berikut :

a. Studi Pustaka

Pada penelitian ini Penulis menelaah teori-teori yang bersumber dan bukubuku teks dan jurnal.

b. Penelitian Lapangan

Pada penelitian ini Penulis mengadakan penelitian langsung pada Badan Pengelola Keuangan dan Aset daerah Kabupaten Musi Banyuasin dengan cara sebagai berikut :

1) Wawancara

Pada penelitian ini Penulis melakukan wawancara berstruktur, dimana peneliti bebas mewawancarai dan tidak menggunakan pedoman wawancara yang telah tersusun secara sistematis dan lengkap untuk pengumpulan data.

2) Dokumentasi

Pada penelitian ini Penulis mendokumentasikan struktur organisasi Badan Pengelola Keuangan dan Aset Daerah (BPKAD) Kabupaten Musi Banyuasin.

\section{Teknik Analisis Data}

\section{Uji Validitas}

Priyatno (2016:17), menyatakan untuk mengukur validitas tidaknya setiap faktor dapat dilakukan dengan cara mengkorelasikan skor faktor tertentu dengan skor total, dengan menggunakan korelasi product moment dengan angka dasar yang dikemukakan oleh Pearson, sebagai berikut :

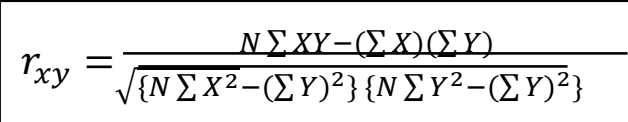




\section{Uji Reliabilitas}

Suatu konstruk atau variabel dikatakan reliabel jika memberikan nilai CronbachAlpha $>0.60$. Berikut ini adalah rumus reliabilitas :

$$
r_{11}=\frac{(k)}{(k-1)}\left(1-\frac{\sum \sigma_{b}^{2}}{\sigma_{t}^{2}}\right)
$$

\section{Analisis Regresi Linier Sederhana}

Sunyoto (2013:110), menyatakan persamaan regresi linier sederhana adalah sebagai berikut:

$\mathbf{Y}=\mathbf{a}+\mathbf{b X}+\mathbf{e}$

\section{Pengujian Hipotesis}

Untuk melakukan pengujian hipotesis digunakan alat ukur sebagai berikut:

1. Uji Korelasi (R)

Rumus koefisien korelasi r Pearson adalah sebagai berikut :

$$
\mathrm{r}=\frac{n \sum x y-\sum x \sum y}{\sqrt{n\left(\sum x^{2}\right)-\left(\sum x\right)^{2} \sqrt{n\left(\sum y^{2}\right)}-\left(\sum y\right)^{2}}}
$$

2. Koefisien Determinasi $\left(\mathrm{R}^{2}\right)$

Rumus koefesien determinasi adalah sebagai berikut :

$$
\mathrm{KD}=\mathrm{r}^{2} \mathrm{X} 100 \%
$$

3. Uji Signifikasi Pengaruh Parsial (Uji t)

Rumus uji signifikansi pengaruh (uji t) adalah sebagai berikut :

$$
\mathrm{t}=\frac{\overline{\mathrm{X}}_{1}-\overline{\mathrm{X}_{2}}}{\mathrm{~S}_{\mathrm{x}-\mathrm{x}}}
$$

\section{HASIL DAN PEMBAHASAN}

Analisis Pelaksanaan Sistem Pengendalian Intern pada Badan Pengelola Keuangan dan Aset Daerah Kabupaten Musi Banyuasin

Berdasarkan hasil kuesioner sebagaimana telah dijelaskan di atas, maka dapat dikatakan bahwa Sistem Pengendalian Intern Pemerintah pada Badan 
Pengelola Keuangan dan Aset Daerah Kabupaten Musi Banyuasin telah dilaksanakan dengan baik berdasarkan hasil dari penilaian responden. Hal ini didukung dengan indikator penelitian yaitu unsur-unsur sistem pengendalian intern pemerintah:

\section{Lingkungan pengendalian}

Penegakan integritas dan nilai etika pada Badan Pengelola Keuangan dan Aset

Daerah Kabupaten Musi Banyuasin telah disusun dan diterapkan dengan baik sehingga menimbulkan perilaku yang positif dan kondusif dalam lingkungan kerjanya, komitmen terhadap kompetensi telah dilaksanakan secara efektif. Hal ini dapat dilihat dengan adanya pelatihan dan pembimbingan untuk membantu pegawai dalam mempertahankan dan meningkatkan kompetensi pekerjaannya, kepemimpinan telah berjalan secara kondusif. Hal ini dapat dilihat dengan adanya interaksi antara pmpinan instansi dengan pejabat yang tingkatannya lebih rendah, struktur organisasi yang ada telah disusun dan diterapkan sesuai dengan kebutuhan, pendelegasian wewenang dan tanggung jawab telah diserahkan kepada pegawai yang tepat sesuai dengan tingkat tanggung jawabnya, telah disusun dan diterapkannya kebijakan yang sehat tentang pembinaan sumber daya manusia, perwujudan peran aparat pengawasan intern pemerintah telah berjalan secara efektif sehingga mampu memberikan keyakinan yang memadai atas ketaatan, kehematan, efisiensi, dan efektivitas pencapaian tujuan penyelenggaraan tugas dan fungsi instansi pemerintah, hubungan kerja yang baik telah berjalan secara efektif.

2. Penilaian Risiko

Identifikasi risiko dan analisis risiko pada Badan Pengelola Keuangan dan Aset Daerah Kabupaten Musi Banyuasin telah dilaksanakan dengan baik.

3. Kegiatan pengendalian

Review atas kinerja instansi pemerintah pada Badan Pengelola Keuangan dan Aset Daerah Kabupaten Musi Banyuasin telah dilaksanakan dengan baik, pembinaan sumber daya manusia telah dilakukan dengan memadai. Hal ini dapat dilihat dari adanya strategi perencanaan dan pembinaan sumber daya manusia yang mendukung visi dan misi Pemerintah Daerah, pengendalian atas pengelolaan sistem informasi telah dilaksanakan dengan baik, pengendalian fisik 
atas aset telah dilaksanakan dengan baik, penetapan dan reviu atas indikator dan ukuran kinerja telah dilaksanakan secara memadai. Dalam hal pemisahan fungsi, pimpinan telah menjamin bahwa seluruh aspek utama transaksi atau kejadian tidak dikendalikan oleh 1 (satu) orang, penetapan syarat dan ketentuan tentang otorisasi atas transaksi dan kejadian penting telah dilaksanakan dengan baik, transaksi dan kejadian telah diklasifikasikan dengan tepat dan dicatat dengan segera sehingga menghasilkan pencatatan yang akurat dan tepat waktu, pembatasan akses atas sumber daya telah dilaksanakan dengan baik yang kemudian dilakukan reviu atas pembatasan tersebut, penetapan dan pencatatan akuntabilitas terhadap sumber daya telah dilaksanakan dengan baik dan diberikan kepada pegawai yang bertanggung jawab, instansi telah memiliki, mengelola, memelihara, dan secara berkala memutakhirkan dokumentasi yang mencakup seluruh sistem pengendalian intern serta transaksi dan kejadian penting.

4. Informasi dan komunikasi

Komunikasi atas informasi pada Badan Pengelola Keuangan dan Aset Daerah Kabupaten Musi Banyuasin telah diselenggarakan secara efektif yang mencakup pengelolaan, pengembangan, dan pembaharuan sistem informasi secara terus menerus.

\section{Pemantauan}

Pada Badan Pengelola Keuangan dan Aset Daerah Kabupaten Musi Banyuasin telah menyelenggarakan pemantauan berkelanjutan secara efektif sehingga dapat memicu evaluasi terpisah pada saat persoalan teridentifikasi, tindak lanjut rekomendasi audit dan reviu lainnya telah dilaksanakan sesuai dengan mekanisme yang telah ditetapkan.

Walaupun demikian, Penulis menemukan beberapa kelemahan yaitu sebagai berikut:

1. Pimpinan instansi masih kurang intensif dalam melakukan interaksi dengan pejabat pada tingkatan yang lebih rendah. Seharusnya pimpinan melakukan interaksi secara efektif dengan bawahannya agar terjalin kerja sama yang baik dan tidak terjadi adanya kesenjangan atau batasan yang terlalu jauh antara pegawai dengan pimpinannya. 
2. Strategi perencanaan dan pembinaan sumber daya manusia dalam mendukung pencapaian visi dan misi kurang dilaksanakan secara efektif. Seharusnya Strategi perencanaan dan pembinaan sumber daya manusia lebih ditingkatkan lagi sehingga mampu menciptakan sumber daya manusia yang berkualitas.

\section{Analisis Efektivitas Pengelolaan Keuangan pada Badan Pengelola Keuangan dan Aset Daerah Kabupaten Musi Banyuasin}

Berdasarkan deskripsi tanggapan responden berkaitan dengan indikatorindikator efektivitas pengelolaan keuangan daerah sebagaimana telah dikemukakan di atas, maka dapat disimpulkan baha efektivitas pengelolaan keuangan daerah pada Badan Pengelola Keuangan dan Aset Daerah Kabupaten Bandung masuk dalam kriteria “Sangat efektif'. Hal ini didukung dengan indikator penelitian yaitu tujuan pengelolaan keuangan daerah:

1. Tanggung jawab

Tugas keuangan pemerintah daerah telah dipertanggungjawabkan kepada lembaga/orang yang berkepentingan yang sah, setiap transaksi berpangkal pada wewenang dan hukum yang berlaku, dan telah melakukan pengawasan yang merupakan tata cara yang efektif untuk menjaga kekayaan uang dan barang, mencegah penyelewengan, dan memastikan semua pendapatan yang sah benarbenar terpungut, jelas sumbernya dan tepat penggunaanya.

2. Mampu melunasi kewajiban keuangan

Keuangan daerah telah ditata sedemikian rupa sehingga mampu melunasi semua ikatan keuangan, jangka pendek maupun jangka panjang.

\section{Kejujuran}

Urusan keuangan telah diserahkan kepada pegawai yang jujur sehingga dapat memperkecil kesempatan untuk berbuat kecurangan.

4. Hasil guna dan kegiatan efisiensi dan efektif

Tata cara mengurus keuangan daerah telah ditata dengan baik sehingga memungkinkan program dapat direncanakan dan dilaksanakan untuk mencapai tujuan pemerintah daerah dengan biaya yang serendah-rendahnya dan dalam waktu yang sesingkat-singkatnya.

5. Pengendalian 
Pegawai yang terlibat dalam keuangan pemerintah daerah telah melaksanakan pengendalian dalam rangka pencapaian tujuan, dan pegawai yang terlibat dalam keuangan pemerintah daerah telah mengusahakan mendapat informasi yang diperlukan untuk memantau pelaksanaan penerimaan dan pengeluaran.

Walaupun demikian, Penulis menemukan beberapa kelemahan yaitu alokasi penggunaan biaya dalam pengurusan keuangan daerah masih belum efisien. Oleh sebab itu perlu adanya peningkatan fungsi pengawasan terhadap segala sesuatu yang berhubungan dengan keuangan daerah.

\section{Analisis dan Pengujian Pengaruh Sistem Pengendalian Intern Pemerintah terhadap Efektivitas Pengelolaan Keuangan pada Badan Pengelola Keuangan dan Aset Daerah Kabupaten Musi Banyuasin}

\section{Pengujian Validitas}

Terlihat bahwa korelasi antara masing-masing indikator terhadap total skor konstruk dari setiap variabel menunjukkan hasil yang signifikan dan menunjukkan bahwa $r$ hitung $>r$ tabel. Sehingga dapat disimpulkan bahwa semua item pertanyaan variabel efektivitas pengelolaan laporan keuangan dinyatakan valid.

\section{Pengujian Reliabilitas}

Hasil uji reliabilitas tersebut menunjukkan bahwa variabel SPIP dan efektivitas pengelolaan laporan keuangan mempunyai koefisien Alpha yang cukup besar yaitu di atas 0,60, sehingga dapat dikatakan semua konsep pengukur masingmasing variabel dari kuesioner adalah reliabel sehingga untuk selanjutnya itemitem pada masing-masing konsep variabel tersebut layak digunakan sebagai alat ukur.

\section{Analisis Persamaan Regresi Linear Sederhana}

Tabel 2

Hasil Regresi Sederhana Coefficients $^{a}$

\begin{tabular}{|ll|r|r|}
\hline \multicolumn{2}{|l|}{} & \multicolumn{2}{|c|}{ Unstandardized Coefficients } \\
\cline { 3 - 4 } Model & \multicolumn{1}{|c|}{ B } & \multicolumn{1}{c|}{ Std. Error } \\
\hline 1 & (Constant) & 5.103 & 4.243 \\
& Sistem_Pengendalian_Intern_Pemerintah & .841 & .107 \\
\hline
\end{tabular}

a. Dependent Variable: Efektivitas_Pengelolaan_Laporan_Keuangan

Sumber: Data diolah, Tahun 2020 
Berdasarkan Tabel 2 dapat diketahui persamaan regresi yang terbentuk adalah :

$$
Y=5,103+0,841 X
$$

Dari persamaan tersebut dapat dijelaskan bahwa :

1. Nilai konstanta sebesar 5,103 artinya jika sistem pengendalian intern pemerintah Kabupaten Musi Banyuasin konstan (nol), maka tingkat efektivitas pengelolaan laporan keuangan sebesar 5,103.

2. Variabel sistem pengendalian intern pemerintah mempunyai hubungan yang positif terhadap efektivitas pengelolaan laporan keuangan Pemerintah Kabupaten Musi Banyuasin.

3. Koefisien sistem pengendalian intern pemerintah memberikan nilai sebesar 0,841 yang berarti bahwa variabel sistem pengendalian intern pemerintah bertambah satu satuan maka variabel efektivitas pengelolaan laporan keuangan bertambah sebesar 0,841 dan sebaliknya.

\section{Pengujian Hipotesis}

\section{Pengujian Korelasi (r)}

Ukuran yang menyatakan keeratan buhungan tersebut adalah koefisien korelasi atau sering disebut dengan korelasi person (pearson product moment). Hasil pengujian korelasi disajikan pada Tabel 3.

Tabel 3

Uji Korelasi (r)

Correlations

\begin{tabular}{|c|c|c|c|}
\hline & & $\begin{array}{c}\text { Sistem_Pengendalian_- } \\
\text { Intern_Pemerintah }\end{array}$ & $\begin{array}{c}\text { Efektivitas_Pengelolaan } \\
\text { _Laporan_Keuangan }\end{array}$ \\
\hline $\begin{array}{l}\text { Sistem_Pengendalian_Inter } \\
\text { n_Pemerintah }\end{array}$ & $\begin{array}{l}\text { Pearson Correlation } \\
\text { Sig. (2-tailed) } \\
\mathrm{N}\end{array}$ & $\begin{array}{r}1 \\
38\end{array}$ & $\begin{array}{r}.796^{*} \\
.000 \\
38\end{array}$ \\
\hline $\begin{array}{l}\text { Efektivitas_Pengelolaan_La } \\
\text { poran_Keuangan }\end{array}$ & $\begin{array}{l}\text { Pearson Correlation } \\
\text { Sig. (2-tailed) } \\
\mathrm{N}\end{array}$ & $\begin{array}{r}.796^{\star *} \\
.000 \\
38\end{array}$ & $\begin{array}{r}1 \\
38\end{array}$ \\
\hline
\end{tabular}

**. Correlation is significant at the 0.01 level (2-tailed).

Sumber: Data diolah, Tahun 2020 
Berdasarkan Tabel 3 di atas diperoleh angka $r$ sebesar 0,796. Hal ini menunjukkan bahwa terjadi hubungan yang kuat antara ksistem pengendalian intern pemerintah terhadap efektivitas pengelolaan laporan keuangan pada Badan Pengelola Keuangan dan Aset Daerah Kabupaten Musi Banyuasin. Hal ini dikarenakan nilai $\mathrm{R}$ berada diantara 0,60 sampai dengan 0,799 dengan intepretasi koefisien kolerasi kuat.

\section{Koefisien Determinasi $\left(\mathbf{R}^{2}\right)$}

Koefisien determinasi merupakan besaran yang menunjukkan besarnya variasi variabel dependen yang dapat dijelaskan oleh variabel independennya. Nilai koefisien determinasi ditentukan dengan nilai $\mathrm{R}^{2}$ sebagaimana dapat dilihat pada table di bawah ini :

Tabel 4

Koefisien Determinasi

Model Summary

\begin{tabular}{|c|c|c|c|c|}
\hline Model & $\mathrm{R}$ & $\mathrm{R}$ Square & Adjusted R Square & Std. Error of the Estimate \\
\hline 1 & $.796^{\mathrm{a}}$ & .633 & .623 & 3.351 \\
\hline
\end{tabular}

a. Predictors: (Constant), Sistem_Pengendalian_Intern_Pemerintah

Sumber: Data Diolah, Tahun 2020

Hasil perhitungan regresi dapat diketahui bahwa koefisien determinasi $\mathrm{R}^{2}$ yang diperoleh sebesar 0,796. Hal ini berarti 79,60\% variasi variabel efektivitas pengelolaan laporan keuangan pada Badan Pengelola Keuangan dan Aset Daerah Kabupaten Musi Banyuasin dapat dijelaskan oleh variabel sistem pengendalian intern sedangkan sisanya sebesar 21,40\% diterangkan oleh variabel lain yang tidak dianalisis dalam penelitian ini.

\section{Uji t}

Untuk menguji pengaruh variabel bebas terhadap variabel terikat menggunakan uji t. Hasil perhitungan diperoleh sebagai berikut : 


\begin{tabular}{|c|c|c|c|c|c|}
\hline \multicolumn{6}{|c|}{$\begin{array}{c}\text { Tabel } 5 \\
\text { Hasil Uji t } \\
\text { Coefficients }^{a}\end{array}$} \\
\hline \multirow[b]{2}{*}{ Model } & \multicolumn{2}{|c|}{$\begin{array}{l}\text { Unstandardized } \\
\text { Coefficients }\end{array}$} & $\begin{array}{l}\text { Standardized } \\
\text { Coefficients }\end{array}$ & \multirow[b]{2}{*}{$\mathrm{T}$} & \multirow[b]{2}{*}{ Sig. } \\
\hline & B & Std. Error & Beta & & \\
\hline 1 (Constant) & 5.103 & 4.243 & & 1.203 & .237 \\
\hline $\begin{array}{l}\text { Sistem_Pengendalian_Intern } \\
\text { _Pemerintah }\end{array}$ & .841 & .107 & .796 & 7.880 & .000 \\
\hline
\end{tabular}

Sumber: Data Primer (Diolah), Tahun 2020

Berdasarkan Tabel 5 di atas dapat dilihat bahwa t hitung sebesar 7,880. Untuk mengetahui pengaruh sistem pengendalian intern pemerintah terhadap efektivitas pengelolaan laporan keuangan pada Badan Pengelola Keuangan dan Aset Daerah Kabupaten Musi Banyuasin dengan menggunakan t hitung, maka kita harus membandingkan antara $\mathrm{t}$ hitung dan $\mathrm{t}$ tabel. Apabila $\mathrm{t}$ hitung $>\mathrm{t}$ tabel, maka variabel sistem pengendalian intern pemerintah berpengaruh terhadap efektivitas pengelolaan laporan keuangan pada Badan Pengelola Keuangan dan Aset Daerah Kabupaten Musi Banyuasin. Untuk mengetahui nilai t tabel, maka dapat digunakan persamaaan sebagai berikut: $\mathrm{Df}=\mathrm{n}-\mathrm{k}-1$, di mana $\mathrm{n}$ merupakan total sampel, $\mathrm{k}$ merupakan jumlah variabel independent. Jadi df $=38-1-1=36$. Jadi dapat kita lihat pada tabel t pada df 36 yaitu sebesar 2,02809. Perbandingan t hitung dan t tabel dapat kita lihat bahwa nilai t hitung $>$ dari nilai t tabel, yakni 7,880 > 2.02809. Jadi berdasarkan perbandingan nilai t hitung dan $\mathrm{t}$ tabel, dapat disimpulkan bahwa variabel sistem pengendalian intern pemerintah berpengaruh terhadap efektivitas pengelolaan laporan keuangan pada Badan Pengelola Keuangan dan Aset Daerah Kabupaten Musi Banyuasin.

\section{SIMPULAN}

Sistem pengendalian intern pemerintah pada Badan Pengelola Keuangan dan Aset Daerah Kabupaten Musi Banyuasin sudah memadai hal ini didukung oleh indikator penelitian yaitu unsur-unsur sistem pengendalian intern pemerintah yang terdiri dari lingkungan pengendalian, penilaian risiko, kegiatan pengendalian, informasi dan komunikasi serta pemantauan. Efektivitas pengelolaan keuangan daerah pada Badan Pengelola Keuangan dan Aset Daerah Kabupaten Musi 
Banyuasin sangat efektif hal ini didukung oleh indikator penelitian yaitu tujuan pengelolaan keuangan daerah yang terdiri dari tanggungjawab, mampu memenuhi kewajiban keuangan, kejujuran, hasil guna dan kegiatan efisiensi dan efektif serta pengendalian.

Terdapat pengaruh sistem pengendalian intern pemerintah terhadap efektivitas pengelolaan keuangan daerah pada Badan Pengelola Keuangan dan Aset Daerah Kabupaten Musi Banyuasin. Dari hasil penelitian yang didapat dengan menggunakan perhitungan statistik, maka dapat diketahui bahwa besarnya pengaruh sistem pengendalian intern pemerintah terhadap efektivitas pengelolaan keuangan daerah pada Pemerintah Kabupaten Musi Banyuasin sebesar 79,60\% \% dan sisanya $21,40 \%$ dipengaruhi oleh faktor lain yang tidak diteliti oleh Penulis. Banyak kemungkinan faktor lain yang juga dapat menentukan efektivitas pengelolaan keuangan daerah seperti pengawasan fungsional, penerapan sistem informasi teknologi akuntansi, dan lain-lain.

Pimpinan instansi hendaknya meningkatkan intensitas dalam hal interaksi dengan pejabat yang tingkatannya lebih rendah. Dengan demikian, akan terjalin hubungan dan kerja sama yang baik. Selain itu dapat mengurangi terjadinya batasan yang terlalu jauh antara pimpinan dengan bawahannya. Perlu adanya peningkatan peran pengawasan dalam hal alokasi penggunaan biaya sehingga setiap pengeluaran didasarkan pada skala prioritas sesuai dengan kebutuhan. Untuk peneliti selanjutnya, agar menambah atau memasukan indikator lain ntuk meningkatkan validitas hasil penelitian dan untuk memperjelas lagi pengaruh dari sistem pengendalian intern pemerintah terhadap efektivitas pengelolaan keuangan daerah.

\section{DAFTAR PUSTAKA}

Arikunto, Suharsimi. 2015. Prosedur Penelitian Suatu Pendekatan, Edisi Revisi. Yogyakarta: Rhineka Cipta.

Bastian, Indra. 2012. Audit Sektor Publik. Jakarta: Salemba Empat

Gloria, Sinambow Injilita Bulan, Jantje Tinangon dan Lidia Mawikere. 2017. Pengaruh Kualitas Pengelolaan Keuangan dan Sistem Pengendalian Intern Pemerintah (SPIP) terhadap Efektivitas Pengelolaan Keuangan Daerah pada Inspektorat Pemerintah Kota Manado. Jurnal Riset Akuntansi Going Concorn $12(1)$ 
Halim, Abdul. 2012. Akuntansi Sektor Publik. Jakarta: Salemba Empat.

Kuncoro, Mudrajat. 2016. Motode Riset Untuk Bisnis \& Ekonomi. Jakarta: Erlangga

Mardiasmo. 2013. Otonomi dan Manajemen Keuangan Daerah. Yogyakarta: Andi.

Nordiawan, Deddi. 2014. Akuntansi Sektor Publik. Jakarta: Salemba Empat.

Peraturan Pemerintah Nomor 8 Tahun 2006 tentang Pelaporan Keuangan dan Kinerja Instansi Pemerintah

Peraturan Pemerintah Nomor 12 Tahun 2019 tentang Pengelolaan Keuangan Daerah.

Pemerintah , Nomor 60 Tahun 2008 tentang Sistem Pengendalian Intern , Nomor 55 Tahun 2005 tentang Dana Perimbangan

Priyatno, Duwi 2016, Teknik Mudah dan Cepat Melakukan Analisis Data Penelitian dengan SPSS dan Tanya Jawab Ujian Pendadaran. Yogyakarta: Gava Media

Sugiyono. 2015. Metode Penelitian Kuantitatif Kualitatif dan R\&D. Bandung: Alfabeta

Sunyoto, Danang. 2013. Metode Penelitian Untuk Bisnis. Yogyakarta. CAPS

Undang-undang Nomor 9 Tahun 2015 tentang Pemerintah Daerah 